\title{
Star Struck in Lindau
}

\section{Among the innovations pioneered by John White during his years as CEO of ACM was a new relationship with the Klaus Tschira Foundation that sponsors the Heidelberg}

Laureate Forum $^{\mathrm{a}}$ [HLF] in the third quarter of each year. The attendees include about 200 math or computer science students and recipients of the mathematics Fields Medal, the Nevanlinna Prize, the Abel Prize, and ACM's A.M. Turing award for computer science. I have had the pleasure of attending the first three meetings of the HLF. Since 1951, however, there has been an annual meeting of Nobel laureates ${ }^{\mathrm{b}}$ with support from several organizations including the aforementioned Klaus Tschira Foundation. The HLF is patterned after the Nobel meeting: students meet with a collection of participating laureates. It was decided last year to link these two events by having a Nobel laureate address the participants of the HLF and to have an HLF laureate address the participants of the Nobel annual meeting. As I write this column, I am in the midst of the Nobel meeting in Lindau and, frankly, star struck at meeting people whose names have been in the news for their extraordinary work. I have the honor to be the first of the HLF participants to address the Nobel meeting and if you think this is not a daunting prospect, think again!

My theme, however, is not just the amazing collection of brilliance at both meetings but the clear and increasing role that computing and computer science are playing in basic research. To be sure, computers have long been utilized to make predictions based on theory and to assess measure-

a http://www.heidelberg-laureate- forum.org/

b http://www.lindau-nobel.org/ ments to determine whether the theoretical predictions match the experimental evidence. The 2013 Nobel Prize in Chemistry, however, underscored the potential for using computers to predict biochemical interactions on the basis of computer-based modeling. Three chemists won the Nobel Prize in Chemistry in $2013^{\text {c }}$ "for multiscale models for complex chemical systems." As I meet other basic and experimental scientists at this weeklong event, I am struck by how often computers play a key role in discovery science. That our discipline touches almost everything in the scientific world is not an overstatement.

I met Martin Karplus at this event. He was among the 2013 Nobel laureates and opened my eyes to the incredible complexity of processes found inside cells. This is not a simple sea of liquid in which organelles and chemicals are swimming. The cell actually has a very complex structure, including so-called microtubules that help to guide the transport of molecules where they are needed in the cell. They are like highways inside the cell. There are molecular robots (I am not kidding!) that literally travel along these highways, carrying specific molecules to targets in the cell. This looks sort of like Multiprotocol Label Switching guiding packets along optical channels! Moreover, like the Internet, there are "addresses" to indicate where the robots are sup-

c http://www.nobelprize.org/nobel_prizes/ chemistry/laureates/2013/; Martin Karplus, Arieh Warshel, and Michael Levitt. posed to deliver the molecules. The cells encompass a molecular package switching system (ok, bad pun)! I have not yet learned enough about the way in which the addressing is done, but it is apparently multi-layered and even has the property that a molecule can be targeted to get stuck in an intracellular membrane in addition to being delivered to a target organelle.

The cell uses DNA and RNA to guide the production of proteins by assembling amino acids and by delivering them on the intracellular highway to their destinations. The DNA is used to produce so-called "messenger RNA" that is used in the process of generating proteins using the cell's ribosomes to interpret the RNA and to assemble the prescribed molecular structure. Of course Theorem $206^{\mathrm{d}}$ applies here and I have left out the roles of transfer-RNA and ribosomal-RNA in this process. As we learn more about the internal functionality of cells, and succeed in modeling their operation, we will shed additional light on the plausible paths by which this functionality has evolved. Research is under way to discover by experiment the simplest form of replicating cells and to use computer models to help postulate plausible origins of life.

It would be difficult to overstate the excitement I feel for the role our discipline is playing in surveying the scientific discovery landscape and modeling the processes we find to understand the "how" and maybe the "why" of their operation. This underscores for me and I hope for you, the importance of advancing the state of the art of computing and its capacity to analyze and model the complex phenomena that we are finding all around us at the micro and the macro levels.

d Theorem 206: "Everything is more complicated."

Vinton G. Cerf is vice president and Chief Internet Evangelist at Google. He served as ACM president from 2012-2014.

Copyright held by author. 